\title{
Karakteristik Pelanggan Dan Persepsi Pelanggan Terhadap Pelayanan Puskesmas (Kasus di Kota Kotamobagu dan Kabupaten Bolaang Mongondow Utara, Provinsi Sulawesi Utara)
}

\author{
The Client characteristics and perception \\ to the Community Health Service: \\ Case: Kotamobagu and Bolaang Mongondow \\ Province of Nort Sulawesi
}

\author{
Mutu B. Mokoginta ${ }^{1}$, Basita G. Sugihen ${ }^{2}$, Djoko Susanto ${ }^{3}$, Pang S. Asngari ${ }^{2}$ \\ ${ }^{1}$ Staf Pemda Bolaang Mongondow \\ ${ }^{2}$ Departemen Sains Komunikasi dan Pengembangan Masyarakat, \\ Fakultas Ekologi Manusia, Institut Pertanian Bogor
}

\begin{abstract}
s
Clients characteristics and clients perception to the Community health service has been considered as two important aspects. Clients characteristics measured by age, income, works, sex, education background, number of families, distances to community health service, the understanding of mean, goal, and benefit for healthy life. Clients perception to the Community health service measured by medical worker, health services and the cure that has been given has a high level category. Clients satisfaction conducted by Community Health Service tends to be high category.
\end{abstract}

Key words: clients characteristics, clients perception to the community health service

\section{PENDAHULUAN}

Kesehatan adalah salah satu unsur kesejahteraan umum yang harus diwujudkan sesuai dengan cita-cita bangsa Indonesia sebagaimana dimaksud dalam UndangUndang Dasar 1945 melalui pembangunan nasional yang berkesinambungan berdasarkan Pancasila dan Undang-Undang Dasar 1945.

Pembangunan kesehatan, menurut Undang-Undang nomor 23 tahun 1992 tentang kesehatan, diarahkan untuk mempertinggi derajat kesehatan, yang besar artinya bagi pengembangan dan pembinaan sumber daya manusia Indonesia dan sebagai modal bagi pelaksanaan pembangunan nasional yang pada hakikatnya adalah pembangunan manusia Indonesia seutuhnya dan pembangunan seluruh masyarakat Indonesia.

\footnotetext{
${ }^{1}$ Korespondensi Penulis. Telepon: 08124304704

Email: mutu_mokoginta@yahoo.com
}

Visi Indonesia Sehat 2010 adalah: (1) Mewujudkan paradigma sehat yang ditetapkan Visi, yaitu gambaran, prediksi atau harapan tentang keadaan masyarakat Indonesia pada masa datang yaitu Tahun 2010; (2) Adalah gambaran masyarakat Indonesia di masa depan yang penduduknya hidup dalam lingkungan dan perilaku sehat, mampu menjangkau pelayanan kesehatan yang bermutu, adil dan merata serta memiliki derajat kesehatan yang setinggi-tingginya; dan (3) Lingkungan sehat yang kondusif yaitu lingkungan bebas polusi, tersedia air bersih, sanitasi lingkungan, pemukiman yang sehat, perencanaan kawasan berwawasan kesehatan, dan kehidupan masyarakat yang saling tolong menolong.

Agar dapat mewujudkan Visi Indonesia Sehat 2010, maka ditetapkan Misi Pembangunan Kesehatan sebagai berikut: (1) Menggerakkan pembangunan nasional yang berwawasan kesehatan, (2) Mendorong 
Jurnal Penyuluhan, Maret 2009 Vol. 5 No. 1

kemandirian masyarakat untuk hidup sehat, (3) Memelihara dan meningkatkan pelayanan kesehatan yang bermutu, merata dan terjangkau, dan (4) Memelihara dan meningkatkan kesehatan individu, keluarga dan masyarakat beserta lingkungannya.

Dalam era otonomi daerah saat ini terjadi perubahan dimana Organisasi Pemerintah Kabupaten maupun Kota turut serta bertanggung jawab dalam melaksanakan pembangunan kesehatan di wilayahnya. Pemerintah Daerah menetapkan bidang kesehatan sebagai salah satu kewenangan wajib yang harus dilaksanakan oleh Kabupaten/Kota. Penyelenggaraan Kewenangan Wajib oleh Daerah adalah merupakan perwujudan otonomi yang bertanggung jawab, yang pada intinya merupakan pengakuan/pemberian hak dan kewenangan Daerah dalam wujud tugas dan kewajiban yang harus dipikul oleh Daerah.

Pusat Kesehatan Masyarakat (Puskesmas) adalah Unit Pelaksana Teknis (UPT) yang paling dekat dengan masyarakat serta memiliki tugas dan fungsi melayani kesehatan masyarakat yang berada di wilayah kerjanya (kecamatan). Era otonomi daerah saat ini memberi peran yang lebih berat kepada Puskesmas karena masalah kesehatan telah menjadi wewenang dan tanggung jawab daerah, sehingga pemerintah daerah harus mengandalkan kekuatan sendiri dalam penanganan kesehatan masyarakat di daerah.

Puskesmas adalah perangkat Pemerintah Daerah Kabupaten/Kota. Wilayah kerja Puskesmas ditetapkan oleh Bupati atau Walikota, dengan saran teknis dari Kepala Dinas Kesehatan Kabupaten/Kota. Sasaran penduduk yang dilayani oleh sebuah Puskesmas idealnya 30.000 penduduk setiap wilayah Puskesmas.

Menurut Hatmoko (2006), Puskesmas adalah suatu satuan organisasi kesehatan fungsional yang merupakan pusat pengembangan kesehatan masyarakat yang juga membina peranserta masyarakat di samping memberikan pelayanan secara menyeluruh dan terpadu kepada masyarakat di wilayah kerjanya dalam bentuk kegiatan pokok. Dengan kata lain puskesmas mempunyai wewenang dan tanggung jawab atas pemeliharaan kesehatan masyarakat di wilayah kerjanya.

Azwar (Rahayu, 2006:4) Puskesmas adalah suatu unit pelaksana fungsional yang berfungsi sebagai pusat pembangunan kesehatan, serta pusat pelayanan kesehatan tingkat pertama yang menyelenggarakan kegiatannya secara menyeluruh, terpadu, dan berkesinambungan pada suatu masyarakat yang bertempat tinggal dalam suatu wilayah tertentu.

Sebelum Puskesmas didirikan, pelayanan kesehatan di Kecamatan meliputi Balai Pengobatan, Balai Kesejahteraan Ibu dan Anak, Usaha Hygiene Sanitasi Lingkungan, Pemberantasan Penyakit Menular, dan lainlain. Usaha-usaha tersebut masih bekerja sendiri-sendiri dan langsung melapor kepada Kepala Dinas Kesehatan Dati II (sekarang Kabupaten/Kota). Pelayan Balai Pengobatan tidak tahu menahu hal-hal yang terjadi di BKIA, begitu juga pelayan BKIA tidak mengetahui hal-hal yang dilakukan oleh pelayan Hygiene Sanitasi dan sebaliknya (Hatmoko 2006:2), sehingga pelayanan Puskesmas saat ini merupakan suatu pelayanan yang integratif dan terkoordinatif, sehingga sasaran peningkatan kesehatan masyarakat dapat menjadi lebih efisien dan efektif.

Fungsi dan peran Puskesmas adalah: (1) Sebagai Pusat Pembangunan Kesehatan Masyarakat di wilayah kerjanya, (2) Membina peranserta masyarakat di wilayah kerjanya dalam rangka meningkatkan kemampuan untuk hidup sehat, dan (3) Memberikan pelayanan kesehatan secara menyeluruh dan terpadu kepada masyarakat di wilayah kerjanya.

Beberapa penelitian yang menyoroti kinerja Puskesmas dari sisi eksternal atau dari persepsi pelanggan, rata-rata menggambarkan hasil bahwa kinerja Puskesmas serta beberapa pelayanan publik yang lain masih belum menunjukkan kualitas pelayanan yang diharapkan pelanggan, sehingga masih harus dilakukan peningkatan maupun perbaikan kualitas mutu layanan (Rahayu, 2006:8).

Dalam konteks kesehatan, masyarakat, sebenarnya diharapkan tampil menjadi subyek utama yang mengontrol kinerja dari Puskesmas, dengan memberikan persepsi atau cara 
Jurnal Penyuluhan, Maret 2009 Vol. 5 No. 1

pandang tentang suatu obyek yang kemudian ditafsirkan menjadi pesan atau informasi, karena masyarakatlah yang menjadi pelanggan dari Puskesmas yang ada di setiap kecamatan. Masyarakat juga merupakan stakeholder yang penting yang turut menentukan sukses tidaknya kinerja pelayanan yang ditampilkan oleh Puskesmas. Masyarakat yang memiliki derajat kesehatan yang baik akan memberikan kontribusi positif terhadap pembangunan bangsa serta peningkatan kesejahteraan bangsa sehingga kualitas kehidupan masyarakat menjadi semakin baik dan pada akhirnya produktivitas masyarakat akan turut menjadi lebih baik pula.

Karakteristik Pelanggan berkaitan dengan suatu kriteria yang dibutuhkan dalam suatu situasi (Spencer dan Spencer 1993:9). Suatu karakteristik yang diinginkan atau dibutuhkan secara obyektif berada di dalam diri dan ketahanan seseorang ditinjau dari kepribadiannya sehingga seseorang tersebut dapat membawa dirinya dalam berbagai macam situasi.

Beberapa ciri dari karakteristik pelanggan adalah: (1) Motif individu, yaitu sesuatu yang dipikirkan oleh seseorang mengenai keinginan-keinginan dan hal tersebut mengakibatkan suatu tindakan untuk memenuhi keinginan-keinginan tersebut, motif membawa, mengarahkan dan memilih, menentukan sikap dan membawa pada suatu tindakan dan tujuan yang akan dicapai yang berbeda dengan yang lainnya. Seperti dicontohkan bahwa seseorang yang ingin mencapai sesuatu karena motifnya, secara konsisten akan memilih tujuan-tujuan yang diinginkan untuk dia sendiri, dimana mereka akan membuat sesuatu yang berakibat kepada tanggung jawab yang sifatnya pribadi, dan akan menggunakan feedback yang ada untuk dapat melakukan sesuatu dengan lebih baik; (2) Ciri-ciri (Traits), yaitu suatu karakteristik fisikal dan respon yang baik dan konsisten terhadap situasi atau informasi yang ada; (3) Konsep diri, yaitu perilaku seseorang, nilainilai yang dianut dan pencitraan diri. Seperti kepercayaan diri yang merupakan kepercayaan seseorang bahwa ia dapat bertindak secara efektif dalam setiap situasi, ini adalah konsep seseorang mengenai dirinya; dan (4) Pengetahuan, yaitu mengenai informasi yang dimiliki seseorang dalam area tertentu.

Persepsi adalah interpretasi individu akan makna sesuatu baginya dalam kaitan dengan "dunia"nya (Asngari, 1984). Sanders et al (Asngari, 1984) menyebutkan bahwa "Manusia adalah makhluk yang kompleks, tindakannya dipengaruhi oleh banyak hal. . . .. Tindakannya sangat dipengaruhi sesuai perannya dalam setiap situasi, selalu kepada perilaku yang diharapkannya dan subyek untuk mempengaruhi yang lain dalam situasi tertentu"

Dari pernyataan Sanders, dapat disimpulkan bahwa persepsi individu terhadap lingkungannya merupakan faktor penting dan menentukan tindakannya. Sejalan dengan pernyataan Litterer (Asngari, 1984), yang menyatakan bahwa persepsi sangat penting untuk mengetahui penyusunan atau organisasi tingkah laku seseorang. Menurut Litterer, seseorang bertindak atas dasar sesuatu yang dipikirkan, diketahui atau dimengertinya. Karena itu pula, Ittelson dan Cantril (Asngari, 1984) menyatakan bahwa: “. . . "penerimaan memainkan peran penting dan sentral dalam kehidupan kita . . . kajian tentang persepsi adalah salah satu yang paling lama, dibandingkan aktifitas manusia saat ini . . . lewat persepsi . . . kita dapat berhubungan dengan dunia" (“. . . perceiving plays such an important and central role in our living . . . the study of perception is one of the oldest, as well as most recent activities of mankind. . . Trough perception. . we come in contact with the world").

Pembentukan persepsi menurut Litterer (Asngari, 1984), ada keinginan atas kebutuhan manusia untuk mengetahui dan mengerti dunia tempat ia hidup, dan mengetahui makna dari informasi yang diterimanya. Orang bertindak sebagian dilandasi oleh persepsi mereka pada suatu situasi. Di lain pihak, pengalamannya berperan pada persepsi orang itu menurut Stogdill, Hilgard, dan Sanders et al (Asngari 1984).

Litterer (Asngari, 1984) menunjukkan bahwa persepsi orang dipengaruhi oleh pandangan seseorang pada suatu keadaan, 
Jurnal Penyuluhan, Maret 2009 Vol. 5 No. 1

fakta atau tindakan. Karena itu individu perlu mengerti dengan jelas tugas dan tanggung jawab yang diberikan kepadanya. Menurut Litterer (Asngari, 1984): Salah satu faktor dasar persepsi adalah kemampuan orangorang mengumpul fakta-fakta yang terbatas dan bagian-bagian informasi kemudian menyusun dalam gambaran yang utuh. Proses ini merupakan peran penting dalam persepsi (One of the basic factors in perceptions is the ability of people to take a limited number of facts and pieces of information and fit them into a whole picture. This process of closure plays a central role in perception). Walaupun seseorang hanya mendapat bagian-bagian informasi, dia dengan cepat menyusunnya menjadi suatu gambaran yang menyeluruh dan orang itu akan menggunakan informasi yang diperolehnya untuk menyusun gambaran yang menyeluruh.

Desiderato (Rakhmat, 2005) menggambarkan persepsi sebagai pengalaman tentang obyek, peristiwa atau hubunganhubungan yang diperoleh dengan menyimpulkan informasi dan menafsirkan pesan. Persepsi ialah memberikan makna pada stimuli inderawi. Hubungan sensasi dengan persepsi sudah jelas. Sensasi adalah bagian dari persepsi. Walaupun begitu, menafsirkan makna informasi inderawi tidak hanya melibatkan sensasi tetapi juga atensi, harapan, motivasi dan memori. Masalah penelitian ini adalah (1) bagaimanakah karakteristik pelanggan puskesmas di Kota Mobagu dab Kab. Bolaang Mongondow? dan (2) bagaimanakah persepsi pelanggan terhadap layanan puskesmas di Kota Mobagu dab Kab. Bolaang Mongondow? Tujuan penelitian ini adalah (1) untuk menganalisis karakteristik pelanggan puskesmas di Kota Mobagu dab Kab. Bolaang Mongondow, (2) Menganalisis persepsi pelanggan terhadap layanan puskesmas di Kota Mobagu dab Kab. Bolaang Mongondow

\section{METODE PENELITIAN}

Desain penelitian dirancang berbentuk deskriptif korelasional. Penelitian dilaksanakan di Kota Kotamobagu dan Kabupaten Bolaang Mongondow Utara, Provinsi
Sulawesi Utara. Sampel pelanggan Puskesmas di Kota Kotamobagu diambil berdasarkan jumlah kunjungan tahun 2006 (65.117 jiwa) berpedoman pada formula Slovin dengan presisi $10 \%$, $\left(\mathrm{e}^{2}=0.01\right)$, didapat $\mathrm{n}=100$, demikian dengan perhitungan sampel pelanggan Puskesmas di Kabupaten Bolaang Mongondow Utara yang diambil berdasarkan jumlah kunjungan tahun 2006 (36.617 jiwa) berpedoman pada formula Slovin dengan presisi $10 \%\left(\mathrm{e}^{2}=0,01\right)$, didapat $\mathrm{n}=100$. Pengumpulan data sebelumnya dilakukan uji validitas dan uji reliabilitas data. Analisis data menggunakan korelasi dari Pearson Product Moment, yaitu melihat keeratan dan kesearahan hubungan antar peubah.

\section{HASIL DAN PEMBAHASAN}

\section{Karakteristik Pelanggan Puskesmas}

Karakteristik sampel pelanggan Puskesmas dalam penelitian ini adalah umur, pendapatan, pekerjaan, jenis kelamin, pendidikan, jumlah anggota keluarga, jarak tempat tinggal ke Puskesmas, pengertian makna, tujuan dan manfaat hidup sehat di dua lokasi penelitian (Kota Kotamobagu dan Kabupaten Bolaang Mongondow Utara). Hal tersebut dapat dilihat pada Tabel 1, Tabel 2, dan Tabel 3. Umur pelanggan yang terendah terdapat di Kota Kotamobagu (16 tahun) dan umur tertinggi terdapat di Kabupaten Bolaang Mongondow Utara (81 tahun). Sampel pelanggan perempuan lebih banyak ditemukan di Kota Kotamobagu (63\%).Sebaran pendapatan pelanggan dibawah Rp.500.00 per bulan lebih banyak ditemukan di Kabupaten Bolaang Mongondow Utara (44\%). Sebaran pekerjaan pelanggan sebagai tani lebih banyak terdapat di Kabupaten Bolaang Mongondow Utara sebanyak 48\%. Sebaran pendidikan responden setingkat SMA lebih banyak di Kota Kotamobagu yakni 50\%. Sebaran jumlah anggota keluarga antara satu sampai tiga orang seimbang di dua lokasi yakni $48 \%$ dan Jarak tempat tinggal pelanggan ke Puskesmas antara 50 sampai dengan 1640 meter lebih banyak di Kota Kotamobagu yakni $75 \%$. 
Jurnal Penyuluhan, Maret 2009 Vol. 5 No. 1

Dalam melihat pengertian tentang makna, tujuan dan manfaat hidup sehat dilakukan pengukuran skala 1 - 4, sangat rendah sama dengan 1 dan sangat tinggi sama dengan 4. Pengertian makna hidup sehat dari pelanggan Puskesmas secara keseluruhan dapat dikatakan baik. Nilai Rataan Skor Pengertian Makna, Tujuan dan Manfaat Hidup Sehat disajikan pada Tabel 2.

Pengertian makna hidup sehat (Tabel 3) di Kota Kotamobagu sebagian besar berada pada kategori yang sangat tinggi sebesar 53,33 persen dan di Kabupaten Bolaang
Mongondow Utara sebagian besar berada pada kategori yang tinggi sebesar 55,33 persen, yang terdiri dari indikator Pengertian hidup sehat; Orientasi hidup sehat; dan Kesadaran hidup sehat. Sebagian besar pelanggan Puskesmas di kedua lokasi penelitian sudah cukup memiliki pengertian tentang makna hidup sehat mulai dari sanitasi, pengolahan air limbah, penggunaan jamban yang baik dan benar dan hal-hal lain yang berkaitan dengan itu. Di Kabupaten Bolaang Mongondow Utara terdapat seorang responden yang memiliki pengertian tentang hidup

Tabel 1. Ciri-ciri Sampel Pelanggan Puskesmas di Dua Lokasi Penelitian

\begin{tabular}{|c|c|c|c|}
\hline \multirow[b]{2}{*}{ No. } & \multirow[b]{2}{*}{ Uraian } & \multicolumn{2}{|c|}{ Lokasi Penelitian } \\
\hline & & $\begin{array}{c}\text { Kota Kotamobagu } \\
(\mathbf{n}=\mathbf{1 0 0}) \\
(\%)\end{array}$ & $\begin{array}{c}\text { Kabupaten Bolaang } \\
\text { Mongondow Utara } \\
(\mathrm{n}=100) \\
(\%)\end{array}$ \\
\hline \multirow[t]{3}{*}{1} & Umur (Tahun) & & \\
\hline & - Rataan & 37,93 & 41,85 \\
\hline & - Kisaran & $16-71$ & $17-81$ \\
\hline \multirow[t]{3}{*}{2.} & Jenis Kelamin & & \\
\hline & - Laki-laki & 37 & 50 \\
\hline & - Perempuan & 63 & 50 \\
\hline \multirow[t]{7}{*}{3.} & Pendapatan Pelanggan per bulan & & \\
\hline & - $\quad<$ Rp. 500.000 & 24 & 44 \\
\hline & - $\quad>$ Rp. 500.000-Rp.750.000 & 25 & 32 \\
\hline & - $\quad>$ Rp. 750.000 -Rp. 1.000 .000 & 10 & 9 \\
\hline & - $\quad>$ Rp. $1.000 .000-$ Rp. 1.250 .000 & 15 & 3 \\
\hline & - $\quad>$ Rp. $1.250 .000-R p .1 .500 .000$ & 13 & 2 \\
\hline & - $\quad>$ Rp. 1.500 .000 & 13 & 10 \\
\hline \multirow[t]{7}{*}{4.} & Pekerjaan Pelanggan & & \\
\hline & - PNS & 22 & 12 \\
\hline & - $\quad$ TNI/Polri & 0 & 0 \\
\hline & - Pensiunan & 4 & 4 \\
\hline & - $\quad$ Swasta & 19 & 13 \\
\hline & - Tani & 30 & 48 \\
\hline & - Ibu Rumah Tangga & 25 & 23 \\
\hline \multirow[t]{5}{*}{5.} & Pendidikan Pelanggan & & \\
\hline & - SD & 18 & 24 \\
\hline & - SMP & 17 & 25 \\
\hline & - $\quad$ SMA & 50 & 45 \\
\hline & - $\quad$ Perguruan Tinggi & 15 & 6 \\
\hline \multirow[t]{5}{*}{6.} & $\begin{array}{l}\text { Jumlah Anggota Keluarga Pelanggan } \\
\text { (orang) }\end{array}$ & & \\
\hline & $-1 \mathrm{~s} / \mathrm{d} 3$ & 48 & 48 \\
\hline & $-\quad 4 \mathrm{~s} / \mathrm{d} 6$ & 47 & 46 \\
\hline & $-\quad 7 \mathrm{~s} / \mathrm{d} 9$ & 5 & 6 \\
\hline & $->9$ & 0 & 0 \\
\hline \multirow[t]{5}{*}{7.} & $\begin{array}{l}\text { Jarak Tempat Tinggal Pelanggan ke } \\
\text { Puskesmas (meter) }\end{array}$ & & \\
\hline & $-50-1640$ & 75 & 50 \\
\hline & - $\quad 1641-3230$ & 19 & 28 \\
\hline & $-\quad 3231-4820$ & 5 & 4 \\
\hline & - $\quad 4821-6410$ & 1 & 18 \\
\hline
\end{tabular}


Jurnal Penyuluhan, Maret 2009 Vol. 5 No. 1

sehat yang sangat rendah yakni 10,0 persen dengan pengertian hidup sehat yang rendah khususnya pengertian dalam hal sanitasi, pengolahan air limbah, wc, dan lain-lain, di mana mereka menyatakan bahwa mereka sangat tidak mengerti (kategori sangat rendah) dan tidak mengerti (kategori rendah) mengenai hal tersebut.

Orientasi hidup sehat, khususnya kegiatan sehari-hari dengan sarana air bersih, dengan kategori rendah masih terdapat di Kabupaten Bolaang Mongondow Utara, hal ini tidak terlalu berarti karena umumnya di kedua lokasi penelitian memiliki orientasi hidup sehat dengan kategori tinggi dan sangat tinggi. Di Kota Kotamobagu, kesadaran hidup sehat dengan kategori tinggi terdapat jumlah yang paling besar. Tingkat pendidikan responden pelanggan Puskesmas yang sudah cukup baik di Kota Kotamobagu membuat mereka semakin "aware" terhadap kesehatan dan kesadaran hidup sehat menjadi suatu hal yang penting bagi mereka.

Pengertian tujuan hidup sehat (Tabel 3) sebagian besar berada pada kategori tinggi sebesar 56,00 persen di Kota Kotamobagu dan sebesar 56,00 persen di Kabupaten Bolaang Mongondow Utara, yang terdiri dari indikator Program pelayanan kesehatan; Partisipasi program; dan Dampak program kesehatan. Terlihat bahwa pengertian tentang tujuan hidup sehat khususnya pemahaman tentang program pelayanan kesehatan masyarakat yang rendah masih terdapat di Kota Kotamobagu dan di Kabupaten Bolaang Mongondow Utara. Walaupun kurang berarti jika dibandingkan dengan kategori tinggi dan sangat tinggi, namun ternyata masih ada responden yang belum memahami tujuan program pelayanan kesehatan yang diselenggarakan petugas kesehatan Puskesmas untuk peningkatan derajat dan kualitas kesehatan masyarakat, dan berpikir bahwa puskesmas adalah tempat yang akan dikunjungi jika sakit.

Pemahaman tentang program pelayanan kesehatan masyarakat yang didapat dari pengetahuan sendiri atau partisipasi aktif anggota masyarakat Puskesamas, masih ditemukan dengan kategori rendah di Kota Kotamobagu dan di Kabupaten Bolaang Mongondow Utara. Hal ini menunjukkan sebagian anggota masyarakat pelanggan Puskesmas masih tidak mau tahu tentang program kesehatan yang ada di wilayahnya dan bersifat pasif dalam mencari pengetahuan tentang itu. Hal ini disebabkan masing-masing memiliki kesibukan sendiri dan berpikir bahwa mereka yang berkecimpung di bidang itulah yang harus menyampaikan kepada mereka seperti para petugas kesehatan maupun lembaga swadaya masyarakat (LSM) yang bergerak di bidang kesehatan masyarakat.

Kategori terbesar adalah partisipasi program pelayanan kesehatan yang tinggi yaitu di Kota Kotamobagu, ini menunjukkan pelanggan Puskesmas di Kota Kotamobagu lebih memiliki partisipasi aktif dalam hal pengetahuan yang dicari sendiri mengenai program pelayanan kesehatan.

Pemahaman tentang dampak positif dari program pelayanan kesehatan masyarakat masih terdapat kategori sangat rendah di Kota Kotamobagu. Kota Kotamobagu yang lebih maju dari Kabupaten Bolaaang Mongondow Utara menunjukkan kesenjangan yang cukup nyata di mana di satu sisi menunjukkan tingkat partisipasi program pelayanan kesehatan yang tinggi sementara di sisi lain masih terdapat pelanggan yang kurang memahami dampak positif program pelayanan kesehatan serta kerugian-kerugian ekonomi, sosial yang dialami jika mendapat peran sakit. Secara

Tabel 2. Nilai Rataan Skor Pengertian Makna, Tujuan dan Manfaat Hidup Sehat

\begin{tabular}{lllllll}
\hline \multirow{2}{*}{ Sub Peubah } & \multicolumn{2}{l}{$\begin{array}{l}\text { Kota Kotamobagu } \\
(\mathrm{n}=100)\end{array}$} & \multicolumn{2}{l}{$\begin{array}{l}\text { Kabupaten Bolaang } \\
\text { Mongondow Utara } \\
(\mathrm{n}=100)\end{array}$} & \multicolumn{2}{c}{ Total Rataan Skor } \\
\cline { 2 - 7 } & Skor & Kategori & Skor & Kategori & Skor & Kategori \\
\hline $\begin{array}{l}\text { Pengertian Makna } \\
\text { Hidup Sehat (X1.7) }\end{array}$ & 3,52 & Tinggi & 3,35 & Tinggi & 3,44 & Tinggi \\
\hline $\begin{array}{l}\text { Pengertian Tujuan } \\
\text { Hidup Sehat (X1.8) }\end{array}$ & 3,20 & Tinggi & 3,23 & Tinggi & 3,22 & Tinggi \\
\hline $\begin{array}{l}\text { Pengertian Manfaat } \\
\text { Hidup Sehat (X1.9) }\end{array}$ & 3,56 & Tinggi & 3,38 & Tinggi & 3,47 & Tinggi \\
\hline
\end{tabular}

Keterangan: 1-2 = Rendah; >2-3 = Sedang; >3-4 = Tinggi 
Jurnal Penyuluhan, Maret 2009 Vol. 5 No. 1

umum pengertian tujuan hidup sehat pelanggan Puskesmas dalam penelitian ini dapat dikatakan baik dilihat dari pengertian program pelayanan kesehatan, partisipasi program dan dampak program kesehatan.

Pengertian manfaat hidup sehat (Tabel 3) sebagian besar berada pada kategori sangat tinggi sebesar 55,50 persen di Kota Kotamobagu dan kategori tinggi sebesar 49,50 persen di Kabupaten Bolaang Mongondow Utara, yang terdiri dari indikator Manfaat kualitas hidup sehat dan Harapan kualitas hidup sehat. Secara umum, pengertian tentang manfaat hidup sehat dalam penelitian ini tergolong baik. Kecuali di Kabupaten Bolaang Mongondow Utara yang masih terdapat pelanggan yang memiliki pemahaman yang rendah tentang terciptanya masyarakat sejahtera, memiliki motivasi tinggi dan mau bekerja keras akibat dari kualitas hidup yang baik.

Harapan, yaitu keinginan agar masyarakat setempat menjadi lebih maju akibat kualitas kesehatan yang baik, rata-rata di kedua wilayah ini memiliki kategori sangat tinggi di Kota Kotamobagu. Mereka menyatakan bahwa mereka sangat ingin masyarakat menjadi maju karena kualitas kesehatan yang baik.

\section{Persepsi Pelanggan terhadap Pelayanan Puskesmas}

Peubah Persepsi Pelanggan terhadap Pelayanan Puskesmas terdiri dari sub peubah Petugas Kesehatan, Layanan Kesehatan dan Obat yang Diberikan. Sub peubah Petugas Kesehatan terdiri dari indikator Perlakuan yang tidak membedakan, simpati dan motivasi yang diberikan petugas kesehatan, perlakuan yang manusiawi dari petugas kesehatan, penjelasan yang diberikan oleh petugas kesehatan, keterbukaan pasien mengenai penyakitnya, anamnesa/interviuw oleh petugas kesehatan dan pilihan pasien terhadap petugas kesehatan. Semua yang tercakup dalam sub-sub peubah ini berada pada skala pengukuran 1 sampai dengan 4, kecuali indikator pilihan pasien terhadap petugas kesehatan dengan skala pengukuran 0 sampai dengan 1.

Nilai rataan skor Persepsi pelanggan terhadap Pelayanan Puskesmas yaitu 3,07 (tinggi). Kelompok responden di Kota

Tabel 3. Ciri-ciri Pelanggan Berdasarkan Pengertian Makna,

Tujuan dan Manfaat Hidup Sehat di Dua Lokasi

\begin{tabular}{|c|c|c|c|}
\hline \multirow[t]{3}{*}{ No. } & \multirow{3}{*}{ Uraian } & \multicolumn{2}{|c|}{ Lokasi Penelitian } \\
\hline & & Kota Kotamobagu $(n=100)$ & $\begin{array}{c}\text { Kabupaten Bolaang } \\
\text { Mongondow Utara }(n=100)\end{array}$ \\
\hline & & $\%$ & $\%$ \\
\hline \multirow[t]{6}{*}{1.} & $\begin{array}{l}\text { Pengertian Makna } \\
\text { Hidup Sehat }\end{array}$ & & \\
\hline & - Sangat rendah & 0,00 & 0,33 \\
\hline & - $\quad$ Rendah & 1,33 & 4,33 \\
\hline & - $\quad$ Tinggi & 45,33 & 55,33 \\
\hline & - Sangat tinggi & 53,33 & 40,00 \\
\hline & Total & 100,00 & 100,00 \\
\hline \multirow[t]{6}{*}{2.} & $\begin{array}{l}\text { Pengertian Tujuan } \\
\text { Hidup Sehat }\end{array}$ & & \\
\hline & - Sangat rendah & 2,33 & 0,33 \\
\hline & - Rendah & 8,67 & 9,33 \\
\hline & - $\quad$ Tinggi & 56,00 & 56,00 \\
\hline & - Sangat tinggi & 33,00 & 34,33 \\
\hline & Total & 100,00 & 100,00 \\
\hline \multirow[t]{6}{*}{3.} & $\begin{array}{l}\text { Pengertian Manfaat } \\
\text { Hidup Sehat }\end{array}$ & & \\
\hline & - Sangat rendah & 0,00 & 0,00 \\
\hline & - $\quad$ Rendah & 0,00 & 6,00 \\
\hline & - $\quad$ Tinggi & 44,50 & 49,50 \\
\hline & - $\quad$ Sangat tinggi & 55,50 & 44,50 \\
\hline & Total & 100,00 & 100,00 \\
\hline
\end{tabular}


Jurnal Penyuluhan, Maret 2009 Vol. 5 No. 1

Kotamobagu memiliki nilai rata-rata 3,04, lebih rendah dari kelompok responden di Kabupaten Bolaang Mongondow Utara sebesar 3,06. Khusus indikator pilihan pasien terhadap petugas kesehatan (sub peubah petugas kesehatan) diperoleh nilai rataan skor sebesar 0,96, yakni kelompok responden di Kota Kotamobagu memiliki nilai rataan skor sebesar 0,99, lebih tinggi dari kelompok responden di Kabupaten Bolaang Mongon- dow Utara yakni 0.92. Nilai rataan skor Peubah Tidak Bebas Persepsi Pelanggan terhadap Pelayanan Puskesmas disajikan pada Tabel 4.

Persepsi pelanggan terhadap petugas kesehatan (Tabel 5) paling besar berada pada kategori tinggi sebesar 66,50 persen di Kota Kotamobagu dan sebesar 72,50 persen di Kabupaten Bolaang Mongondow Utara, yang terdiri dari indikator Perlakuan yang tidak

Tabel 4. Nilai Rataan Skor Peubah Tidak Bebas Persepsi Pelanggan terhadap Pelayanan Puskesmas

\begin{tabular}{|c|c|c|c|c|c|c|}
\hline \multirow[t]{2}{*}{ Sub Peubah } & \multicolumn{2}{|c|}{$\begin{array}{l}\text { Kota Kotamobagu } \\
(\mathrm{n}=100)\end{array}$} & \multicolumn{2}{|c|}{$\begin{array}{l}\text { Kabupaten Bolaang } \\
\text { Mongondow Utara } \\
(\mathrm{n}=100)\end{array}$} & \multicolumn{2}{|c|}{ Total Rata-rata } \\
\hline & Skor & Kategori & Skor & Kategori & Skor & Kategori \\
\hline $\begin{array}{l}\text { Petugas } \\
\text { kesehatan } \\
(\mathrm{Y} 1.1)) \\
\end{array}$ & 3,03 & Tinggi & 3,05 & Tinggi & 3,04 & Tinggi \\
\hline $\begin{array}{l}\text { Layanan } \\
\text { kesehatan (Y1.2) }\end{array}$ & 3,03 & Tinggi & 3,08 & Tinggi & 3,06 & Tinggi \\
\hline $\begin{array}{l}\text { Obat yang } \\
\text { diberikan (Y1.3) }\end{array}$ & 3,06 & Tinggi & 3,15 & Tinggi & 3,11 & Tinggi \\
\hline Total Rata-rata & 3,04 & Tinggi & 3,09 & Tinggi & 3,07 & Tinggi \\
\hline
\end{tabular}

Keterangan: $1-2$ = Rendah; >2-3 = Sedang; >3-4 = Tinggi

Tabel 5. Ciri-ciri Persepsi Pelanggan Terhadap Pelayanan Puskesmas

\begin{tabular}{|c|c|c|c|}
\hline \multirow[t]{3}{*}{ No. } & \multirow[t]{3}{*}{ Uraian } & \multicolumn{2}{|l|}{ Lokasi Penelitian } \\
\hline & & \multirow{2}{*}{$\begin{array}{l}\text { Kota Kotamobagu } \\
(\mathrm{n}=100) \\
\%\end{array}$} & \multirow{2}{*}{$\begin{array}{l}\text { Kabupaten Bolaang Mongondow } \\
\text { Utara }(\mathrm{n}=100) \\
\%\end{array}$} \\
\hline & & & \\
\hline \multirow[t]{6}{*}{1.} & $\begin{array}{l}\text { Persepsi Pelanggan } \\
\text { terhadap Petugas } \\
\text { Kesehatan (Y1.1) }\end{array}$ & & \\
\hline & - Sangat rendah & 0,83 & 2,50 \\
\hline & - $\quad$ Rendah & 14,17 & 7,33 \\
\hline & - $\quad$ Tinggi & 66,50 & 72,50 \\
\hline & - $\quad$ Sangat tinggi & 18,50 & 17,67 \\
\hline & Total & 100,00 & 100,00 \\
\hline \multirow[t]{6}{*}{2.} & $\begin{array}{l}\text { Persepsi Pelanggan } \\
\text { terhadap Layanan } \\
\text { Kesehatan (Y1.2) }\end{array}$ & & \\
\hline & - $\quad$ Sangat rendah & 0,33 & 1,33 \\
\hline & - Rendah & 13,00 & 10,33 \\
\hline & - $\quad$ Tinggi & 69,67 & 67,33 \\
\hline & - $\quad$ Sangat tinggi & 17,00 & 21,00 \\
\hline & Total & 100,00 & 100,00 \\
\hline \multirow[t]{6}{*}{3.} & $\begin{array}{l}\text { Persepsi Pelanggan } \\
\text { terhadap Obat yang } \\
\text { diberikan (Y1.3) }\end{array}$ & & \\
\hline & - Sangat rendah & 0,00 & 1,00 \\
\hline & - $\quad$ Rendah & 12,33 & 7,00 \\
\hline & - $\quad$ Tinggi & 69,33 & 69,00 \\
\hline & - $\quad$ Sangat tinggi & 18,33 & 23,00 \\
\hline & Total & 100,00 & 100,00 \\
\hline
\end{tabular}


Jurnal Penyuluhan, Maret 2009 Vol. 5 No. 1

membedakan, Simpati/Motivator, Manusiawi, Penjelasan yang diberikan, Keterbukaan pasien, Interviuw petugas dan Pilihan pasien.

Perlakuan yang tidak membedakan tergolong baik, ini ditunjukkan dari tanggapan responden yang sebagian besar dikategorikan tinggi di Kota Kotamobagu dan di Kabupaten Bolaang Mongondow Utara. Umumnya mereka menyatakan para petugas kesehatan tidak membedakan antara pasien kaya dan miskin ataupun mendahulukan pasien yang dikenalnya seperti saudara atau teman.

Simpati dan motivasi yang diberikan petugas kesehatan dinilai baik oleh para responden di kedua lokasi penelitian dengan kategori tinggi baik di Kota Kotamobagu maupun di Kabupaten Bolaang Mongondow Utara. Para responden menyatakan bahwa petugas kesehatan turut merasakan keluhan yang mereka hadapi atau penyakit yang mereka derita serta memberikan motivasi pada mereka agar cepat sembuh dari penyakitnya.

Perlakuan yang manusiawi dari petugas kesehatan ditanggapi baik oleh kebanyakan responden dengan kategori tinggi di Kota Kotamobagu dan di Kabupaten Bolaang Mongondow Utara. Mereka menyatakan para petugas kesehatan memperlakukan mereka secara manusiawi.

Penjelasan yang diberikan oleh petugas kesehatan dinilai baik oleh kebanyakan responden yang diwawancarai dengan kategori tinggi di kedua lokasi penelitian yaitu di Kota Kotamobagu dan di Kabupaten Bolaang Mongondow Utara. Mereka menilai bahwa pertanyaan-pertanyaan tentang masalah kesehatan mereka dijelaskan secara rinci oleh petugas kesehatan Puskesmas.

Keterbukaan pasien mengenai penyakitnya adalah baik, dengan kategori tinggi di Kota Kotamobagu maupun di Kabupaten Bolaang Mongondow Utara. Di sisi lain kecenderungan keterbukaan pasien dengan kategori rendah masih terdapat di Kota Kotamobagu dan di Kabupaten Bolaang Mongondow Utara. Hal ini menunjukkan masih terdapat pasien yang masih enggan bersikap terbuka atas penyakit yang dideri- tanya dan yang menyebabkan hingga ia menderita penyakit tersebut.

Anamnesis oleh petugas kesehatan dinilai cukup baik oleh kalangan responden dan berada pada kategori tinggi di Kota Kotamobagu dan di Kabupaten Bolaang Mongondow Utara. Di Kota Kotamobagu masih terlihat pada kategori yang rendah, mereka menegaskan bahwa petugas kesehatan kurang banyak bertanya mengenai gejala dan riwayat penyakit yang diderita.

Pilihan pasien terhadap petugas kesehatan yang ditanyakan kepada para responden yakni apakah mereka memilih petugas kesehatan yang berpenampilan menarik atau petugas kesehatan yang kurang berpenampilan menarik, umumnya responden memilih petugas kesehatan yang berpenampilan menarik yaitu sebanyak 99,0 persen di Kota Kotamobagu dan di Kabupaten Bolaang Mongondow Utara sebanyak 93,0 persen. Mereka lebih suka memilih petugas yang berpenampilan menarik tanpa menilai kualitas petugas kesehatan yang bersangkutan, walaupun mungkin secara psikologis dapat membantu penyembuhan penyakit.

Persepsi Pelanggan terhadap Layanan Kesehatan (Tabel 5) berada pada kategori tinggi sebesar 69,67 persen di Kota Kotamobagu dan sebesar 67,33 persen di Kabupaten Bolaang Mongondow Utara, yang terdiri dari indikator fasilitas layanan kesehatan, prosedur pelayanan kesehatan dan sistem pelayanan kesehatan.

Fasilitas layanan kesehatan adalah cukup baik ditanggapi oleh para responden dengan kategori tinggi di Kota kotamobagu dan di Kabupaten Bolaang Mongondow Utara. Fasilitas layanan kesehatan dengan kategori rendah juga cukup mencolok di dua lokasi baik di Kota Kotamobagu maupun di Kabupaten Bolaang Mongondow Utara. Responden yang menjawab dengan kategori rendah menyatakan bahwa fasilitas layanan kesehatan yang ada di Puskesmas belum memadai dan belum baik.

Prosedur pelayanan kesehatan tergolong baik dengan kategori tinggi di Kota Kotamobagu dan di Kabupaten Bolaang Mongondow Utara sebesar. Kebanyakan 
responden merasakan prosedur pelayanan kesehatan di puskesmas sudah seperti yang mereka harapkan.

Sistem pelayanan kesehatan tergolong baik serta ditanggapi oleh sebagian besar responden dengan kategori tinggi di Kota Kotamobagu dan di Kabupaten Bolaang Mongondow Utara. Sebagian besar responden menegaskan bahwa cara pelayanan kesehatan yang diberikan kepada mereka cukup baik serta berkaitan dengan keluhan penyakit yang mereka derita.

Persepsi Pelanggan terhadap Obat yang diberikan (Tabel 5) sebagian besar berada pada kategori tinggi sebesar 69,33 persen di Kota Kotamobagu dan sebesar 69,00 persen di Kabupaten Bolaang Mongondow Utara, yang terdiri dari indikator Manfaat obat, Pemberian obat, dan Ketersediaan obat. Manfaat obat yang diberikan sebagian besar ditemukan pada kategori tinggi di Kota Kotamobagu dan di Kabupaten Bolaang Mongondow Utara. Sebagian besar responden yang berada di dua lokasi penelitian ini menyatakan bahwa obat-obat yang diberikan oleh Puskesmas memberikan manfaat bagi kesembuhan mereka.

Pemberian obat dan penjelasan khasiatnya paling besar tergolong pada kategori tinggi baik di Kota Kotamobagu maupun di Kabupaten Bolaang Mongondow Utara. Umumnya responden menegaskan bahwa pemberian obat oleh petugas kesehatan sekaligus pula pemberian penjelasan khasiatnya.

Ketersediaan obat di Puskesmas menurut tanggapan responden pelanggan adalah baik dengan kategori tinggi di Kota Kotamobagu dan di Kabupaten Bolaang Mongondow Utara. Namun demikian ketersediaan obat dengan kategori rendah masih cukup terlihat di Kota Kotamobagu dan Kabupaten Bolaang Mongondow Utara. Responden yang menjawab dengan kategori rendah ini mengeluhkan bahwa selama mereka berkunjung atau berobat ke Puskesmas, obat-obatan yang dibutuhkan tidak selalu tersedia.

\section{KESIMPULAN}

Karakteristik pelanggan khususnya pengertian makna, tujuan dan manfaat hidup sehat berada pada kategori yang tinggi. Persepsi pelanggan terhadap layanan Puskesmas yang terdiri dari aspek petugas kesehatan, layanan kesehatan dan obat yang diberikan berada pada kategori yang tinggi. Kepuasan pelanggan berada pada kategori yang tinggi. Terdapat hubungan nyata antara karakteristik pelanggan dan persepsi pelanggan terhadap layanan Puskesmas.

\section{DAFTAR PUSTAKA}

Asngari, Pang S. 1984. "Persepsi Direktur Penyuluhan Tingkat "Keresidenan" Dan Kepala Penyuluh Pertanian Terhadap Peranan Dan Fungsi Lembaga Penyuluhan Pertanian Di Negara Bagian Texas Amerika Serikat”. Media Peternakan Nomor 2, Volume 9. Fakultas Peternakan Institut Pertanian Bogor.

Hatmoko, 2006. Sistem Pelayanan Dasar Kesehatan Puskesmas. Http://www.freewebtowm.com

Koentjoro, T. 2007. Regulasi Kesehatan di Indonesia. Yogyakarta: CV. Andi Offset.

Maramis W.F. 2006. Ilmu Perilaku Dalam Pelayanan Kesehatan. Surabaya: Airlangga University Press.

Notoatmodjo, S. 2007. Kesehatan Masyarakat, Ilmu dan Seni. Jakarta: PT Rineka Cipta

Rahayu, A. Y. S. 2006. "Pemberdayaan Puskesmas Berdasarkan Pengukuran Kinerja: Kasus Puskesmas di Provinsi DKI-Jakarta." Disertasi. Bogor: Sekolah Pascasarjana IPB.

Rakhmat, J. 2005. Psikologi Komunikasi. Bandung: PT Remaja Rosdakarya.

Spencer, L.M.Jr, dan Spencer S.M. 1993. Competence At Work: Models for Superior Performance. New York, Chichester, Brisbane, Toronto, Singapore: John Wiley and Sons, Inc. 